\section{International Scientific Journal Theoretical \& Applied Science}

Inna Aleksandrovna Serebryanik

Candidate of technical sciences, Associate Professor of the Department of World economy, Irkutsk National Research Technical University, Russia nasamolet@yandex.ru

Alena Viktorovna Druzhinina Student,

Irkutsk National Research Technical University, Russia dashusik_29@mail.ru

SECTION 31. Economic research, finance, innovation, risk management.

\title{
MICROSTATE IN OCEANIA: PROBLEMS AND SOLUTIONS
}

\author{
Abstract: Showing the economic problems of microstates in Oceania. Marked features of this region \\ Investigated possible ways of solving problems of the region. \\ Key words: Oceania, microstate, island state, offshore area, economies of scale. \\ Language: Russian \\ Citation: Serebryanik IA, Druzhinina AV (2015) MICROSTATE IN OCEANIA: PROBLEMS AND \\ SOLUTIONS. ISJ Theoretical \& Applied Science 04 (24): 71-73. \\ Soi: http://s-o-i.org/1.1/TAS*04(24)12 Doi: crossef http://dx.doi.org/10.15863/TAS.2015.04.24.12
}

\section{КАРЛИКОВЫЕ ГОСУДАРСТВА ОКЕАНИИ: ПРОБЛЕМЫ И ПУТИ ИХ РЕШЕНИЯ}

Аннотация: Исследованы экономические проблемы микрогосударств на примере Океании. Обозначены особенности данного региона. Показаны возможные пути решения проблем региона.

Ключевые слова: Океания, микрогоударство, островное государство, оффшорная зона, эффект маситаба.

Государства карлики - это, обычно, те государства площадь и численность населения которых существенно уступают другим государствам. Карликовые государства есть везде - в Европе, Америке, на островах Океании. В ООН зарегистрировано 45 микрогосударств.

Пожалуй, самым известным (эталонным) карликовым государством является Люксембург. Остальные государства часто с ним сравнивают.

Итак, существует два критерия, по которым государство причисляется к карликовым:

1. Численность населения (обычно не превышает 1-1,5 млн. человек);

2. Площадь территории (обычно, меньше Люксембурга).

Карликовые государства Европы обусловлены историческими границами и договорами. Карликовые государства Океании ограничены береговой линией.

Регион Океании представляется особо интересным для изучения. Он представляет собой мир в миниатюре (ландшафт) и удивительно точно воспроизводит все основные тенденции развития современного мира [6-7].

Под Океанией понимается группа островов южной части Тихого океана. Океания включает 21 территорию, объединяющую более 10 тысяч островов, которые зачастую по этнографическому принципу делят на Меланезию (Соломоновы острова, Вануату, Фиджи и Новая Каледония), Микронезию (Палау, Федеративные Штаты Микронезии, Маршалловы острова, Северные Марианские острова, Гуам, Науру и Кирибати) и Полинезию (Тувалу, Уоллис и Футуна, Тонга, Токелау, Самоа, Американское Самоа, Ниуэ, Острова Кука, Французская Полинезия и Питкерн) [5].

После второй Мировой войны регион Океании стали называть «американским внутренним озером», так как здесь доминировал американский интерес. После окончания «холодной войны» интерес к региону пропал, прежде всего, из-за его отдаленности. Большинство из государств в Океании относится к «микрогосударствам». У них крайне слабый экономический потенциал и полная неспособность защитить свой суверенитет [3].

С начала 90-х гг. прошлого века регион стал осваивать Китай. Необходимо отметить, что он делал это еще в XIX веке, но раньше эта была ассимиляция, а теперь китайцы начали составлять конкуренцию местным жителям в бизнесе, торговле. Китай также связывают с 
крупными партиями героина, циркулирующими на островах, а также нелегальной миграцией.

Регион Океании сильно пострадал от оффшорного бизнеса. Только в одном Науру было зарегистрировано более 400 банков, многие оффшоры были задействованы в отмывании денег. Также Океанию преследовали постоянные внутренние конфликты [10].

Рассмотрим особенности отдельных государств карликов в Океании.

Тувалу (26 км² население 10 тыс. чел). Это бывшая колония Великобритании, получившая независимость в 1978 г. Страна состоит из нескольких коралловых островов. Ранее острова принадлежали Британии. На территории Тувалу отсутствуют природные ископаемые, живет на помощь от других стран, считаясь одной из беднейших стран мира. Туризм здесь развивается крайне медленно, хотя имеется потенциал, в том числе и для экотуризма [9]. Забавной статьей доходов государства Тувалу стал Интернет-домен первого уровня .tv Такой домен, конечно, хотели бы иметь телекомпании, и Тувалу продало его за 20 млн. долларов и 2,2 млн. долларов ежегодных взносов.

Науру $\left(21 \mathrm{kм}^{2}\right)$. Это самая маленькая страна Океании и единственное государство без официальной столицы. Находится на юге Тихого океана (Микронезия). В 70-80 гг. фосфориты сделали страну богатейшей. Когда залежи закончились, страна стала оффшором. Вскоре под международным давлением с оффшорным бизнесом пришлось «завязать» и страна погрузилась в экономический кризис [8]. Страну содержит Австралия, используя ее как лагерь, для желающих получить убежище. До 1968 года страной владели Великобритания, Австралия и новая Зеландия, вывозя и продавая фосфориты.

Науру активно зарабатывает на «признании» непризнанных стран. Например, Россия оплачивала 50 млн. долларов за признание Южной Осетии и Абхазии (в форме гуманитарной помощи) [4].

Маршалловы острова (181 км²). Живут благополучно, так как получают помощь от США (здесь расположенный американский военный полигон). На островах тоже были обнаружен залежи фосфоритов, но государство не делало на них ставку и развивало туризм [2]. На островах выращивают кокосовую пальму и ловят рыбу.

Федерация Сент-Китс и Невис. Государство расположено в Вест-Индии (между Северной и Южной Америкой). Живет на доходы от туризма, сельского хозяйства и оффшорного бизнеса. Ежегодно здесь отдыхают более 250 тысяч путешественников. Большая часть - граждане США. Большая часть населения (50 тыс.чел) занята в сфере обслуживания.
Палау - это островное государство (328 островов) и является составной частью Микронезии. Государство полностью зависит от США, формируя бюджет из двух источников - из дотаций со стороны США и поступлений от туризма. Своей валюты в Палау нет, здесь в ходу американский доллар. Палау получал также кредитные деньги от Тайваня, в обмен на признание независимости этой страны. Вообще, противостояние Пекина и Тайбея стало золотой жилой для страны. Палау, кстати, считается раем для дайверов.

Государства карлики Океании стараются получить доход от чего только возможно. Например, долгое время они продавали свой телефонный код для использования его сексоператорами по всему миру (телефонные номера, как правило, четырехзначные). На островах выпускается множество марок, которые высоко ценятся филателистами из разных стран. Также в странах регистрируют суда («дешевый флаг»). Иногда на одну микространу приходится порядка тысячи зарегистрированных судов. Государства Океании приторговывают паспортами, в том числе и дипломатическими.

У государств карликов есть общие проблемы, а есть и специфические. К общим проблема стоит отнести следующие:

1. Проблемы, связанные с микроразмером. Постоянные издержки государства не могут быть распределены между большим количеством человек и, в конечном счете, достичь экономии от эффекта масштаба. Также малый размер сказывается на ряде макроэкономических параметров:

a) Узкая производственная направленность. Как правило, все государства карлики специализируются на производстве одного-двух товаров, услуг и не могут составить конкуренцию на мировом рынке крупным странам;

b) Большая доля государства. Роль государства в экономике стран карликов существенно больше, чем в других странах. Высокий уровень государственных расходов часто становиться причиной большой государственной задолженности;

c) Фиксированный валютный курс. Страны карлики привязывают курс своей валюты к другим валютам. С одной стороны, привязка курса помогает избегать волатильности, с другой стороны, обязывает страну иметь большие финансовые резервы для поддержания стабильности валюты, а их возможности в этом ограничены;

2. Проблемы, связанные с замедленным ростом. Малые государства, по объективным причинам, растут существенно медленней остальных. 
Можно выделить также специфические проблемы региона Океании. Во-первых, он подвержен природным катастрофам. Здесь недостаток пахотной земли и, как следствие, недостаток продуктов питания, а импортные крайне дороги в силу отдаленности. Также в регионе утечка умов.

Карликовые государства могли бы нейтрализовать проблемы и использовать свои преимущества, а именно:

1. Искать новые источники дохода, например, ввести НДС;

2. Диверсифицировать экспорт и торговых партнеров;

3. Накапливать существенные финансовые резервы на случай возможных катастроф;

4. Создавать крупные рынки, путем объединения национальных рынков;

5. Привлекать международные организации и сообщества для решения проблем;

6. Привлекать прямые иностранные инвестиции.

7. И другие

Ряд политологов говорит о том, что карликовые государства Океании являются лишь квазигосударствами, которые не могут решить свои внутренние проблемы и сохранять суверенитет. То есть формально они выглядят как государства, но не имеют способностей к самоуправлению.

Большой размер страны дает ей большие преимущества, например, политическое влияние в мире. Карликовые страны могут получить лишь рядовое членство в ООН и не имеют шансов войти в Совет Безопасности ООН. Однако у карликовых стран Океании есть и преимущества. В этих странах высокий уровень удовлетворенностью жизнью и высокие показатели ее продолжительности. В регионе практически нет проблем, связанных с загрязнением окружающей среды, ибо практически отсутствует промышленность.

Конечно, у стран Океании должен быть собственный путь развития, реализацию этого пути отчасти берет на себя Южнотихоокеанский форум [1], одно он не в силах решить проблемы, связанные с этническими конфликтами в государствах Океании.

\section{References:}

1. Arif Dirlik (1992) The Asia-Pacific Idea: Reality and Representation in the Invention of a Regional Structure. - Journal of World History, Vol.3, No.1, 1992, p. 56.

2. Klesova M (2015) Bjudzhety i bjudzhetiki: na chto zhivut karlikovye gosudarstva. Available: http://rustoria.ru/post/na-chto-zhivutgosudarstva-karliki/ (Accessed: 08.04.2015).

3. (2013) Konkurencija i konfliktnost' v mirovoj jekonomike i politike (Mirovoe razvitie. Vypusk 10)/Otv. red. -Ju.D. Kvashnin, N.V. Toganova, S.V. Utkin. -Moscow: IMJeMO RAN, 2013. $-181 \mathrm{p}$.

4. Lan'kov A (2005) Mal'ki kapitalizma. Kommersant\# Vlast' - №15 ot 18.04.2005, pp. 48.

5. Nikolaev VP (1984) Nezavisimye gosudarstva Okeanii. - Moscow, 1984

6. Okunev I (2011) Political and geographic aspects of stateness (analysis of microstates experience). International journal of humanities and social science. -2011. - Vol. 1, No. 13. pp. 247-251.
7. Okunev IJ (2010) Razmer gosudarstva i uroven' razvitija demokratii. Strany-giganty: problemy territorial'noj stabil'nosti: sbornik dokladov / Pod. red. I.M. Busyginoj, L.V. Smirnjagina, M.G. Filippova. - Moscow: Izdatel'stvo MGIMO (U) MID Rossii, 2010.

8. Okunev IJ (2011) Politiko-geograficheskie aspekty gosudarstvennosti (analiz opyta mikrogosudarstv). Politicheskaja nauka. - 2011. - № 4. - pp. 162-174.

9. Sorokina EV (2010) Mikrogosudarstva Okeanii. Materialy XXIX i XX nauchnyh konferencij po izucheniju Avstralii, Novoj Zelandii i keanii «Juzhno-tihookeanskij region: novye problemy $\mathrm{v}$ bystro menjajushhemsja mire» 30-31 oktjabrja 2009. - Moscow, 2010.

10. Timoshenko VN (2015) Zabytye problemy «nenuzhnogo» regiona. Centr izuchenija mezhdunarodnyh otnoshenij $\mathrm{v}$ AziatskoTihookeanskom regione. Available: http://ru.apircenter.org/archives/172 (Accessed: 08.04.2015). 